\title{
Importance of Common Wall Lizards in the Transmission Dynamics of Tick-Borne Pathogens in the Northern Apennine Mountains, Italy
}

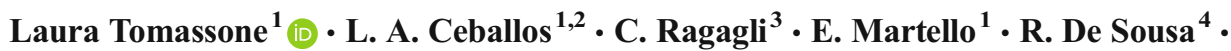 \\ M. C. Stella ${ }^{1} \cdot$ A. Mannelli ${ }^{1}$
}

Received: 20 February 2017 / Accepted: 5 May 2017

(C) Springer Science+Business Media New York 2017

\begin{abstract}
During the investigations on ticks and tick-borne pathogens (TBP) range expansion in the Northern Apennines, we captured 107 Podarcis muralis lizards. Sixtyeight animals were infested by immature Ixodes ricinus, Haemaphysalis sulcata and H. punctata. Borrelia burgdorferi s.l. was detected in $3.7 \%$ of I. ricinus larvae and $8.0 \%$ of nymphs. Together with the species-specific $B$. lusitaniae, we identified B. garinii, B. afzelii and B. valaisiana. Rickettsia spp. (18.1\% larvae, $12.0 \%$ nymphs), namely $R$. monacensis, $R$. helvetica and $R$. hoogstraalii, were also found in I. ricinus. $R$. hoogstraalii was detected in H. sulcata nymphs as well, while the two $H$. punctata did not harbour any bacteria. One out of 16 lizard tail tissues was positive to $R$. helvetica. Our results support the hypothesis that lizards are involved in the epidemiological cycles of TBP. The heterogeneity of $B$. burgdorferi genospecies mirrors previous findings in questing ticks in the area, and their finding in attached I. ricinus larvae suggests that lizards may contribute to the maintenance of different genospecies. The rickettsiae are
\end{abstract}

Electronic supplementary material The online version of this article (doi:10.1007/s00248-017-0994-y) contains supplementary material, which is available to authorized users.

Laura Tomassone

laura.tomassone@unito.it

1 Dipartimento di Scienze Veterinarie, University of Turin, Largo Braccini 2, Grugliasco Turin, Italy

2 Present address: Istituto Zooprofilattico Sperimentale del Piemonte, Liguria e Valle d'Aosta, Turin, Italy

3 UTCB Lucca- Comando Unità per la Tutela Forestale Ambientale e Agroalimentare Carabinieri, Lucca, Italy

4 Centro de estudos de Vectores e Doenças Infecciosas, Instituto Nacional de Saude Dr. Ricardo Jorge, Águas de Moura, Portugal new findings in the study area, and $R$. helvetica infection in a tail tissue indicates a systemic infection. $R$. hoogstraalii is reported for the first time in I. ricinus ticks. Lizards seem to favour the bacterial exchange among different tick species, with possible public health consequences.

Keywords Podarcis muralis $\cdot$ Northern Apennines $\cdot$ Ixodid ticks · Zoonoses · Borrelia burgdorferi s.l. · SFG Rickettsiae

\section{Introduction}

Like other small vertebrates, lizards are suitable hosts for the immature stages of different tick species across Europe and the Mediterranean basin, including Ixodes ricinus, the major vector of tick-borne diseases (TBD) in Europe [45] (Table 1).

Recently, studies have investigated the possible role of lizards as reservoir of TBD agents. The infection by Borrelia burgdorferi s.l. and Rickettsia spp. in tissues and attached ticks was shown in several lizard species (Table 2). Lizards are considered reservoir of Borrelia lusitaniae [42], and some authors also suggest that they may be reservoir of Spotted Fever Group (SFG) rickettsiae, $R$. helvetica and R. monacensis in particular [7, 21, 55]. Interestingly, multiple pathogens (B. burgdorferi s.l., SFG rickettsiae, Anaplasma phagocytophilum) have been shown to co-infect immature I. ricinus ticks feeding on lizards $[14,56]$.

In the Tuscan-Emilian Apennine National Park, Italy, lizards are among the small vertebrate species inhabiting dry and sunny rocky habitats. Our previous studies showed the existence of a complex vertebrate-tick-microbial community in the area. Indeed, I. ricinus, which recently colonized the territory, coexists with I. trianguliceps, Dermacentor marginatus, Haemaphysalis sulcata and H. punctata [30, 40]. A focus of transmission of Rickettsia slovaca and 
Table 1 Bibliographic reports of ixodid tick species feeding on lizards in Europe and Northern Africa

\begin{tabular}{|c|c|c|}
\hline Tick species & Lizard species & Country \\
\hline \multirow[t]{12}{*}{ Ixodes ricinus } & Lacerta agilis & $\begin{array}{c}\text { Germany [42], Netherlands [55], } \\
\text { Hungary [15], Poland [11, 14, } \\
\text { 18], Romania and Slovakia [27] }\end{array}$ \\
\hline & Lacerta viridis & Hungary [15], Slovakia [56] \\
\hline & $\begin{array}{l}\text { Lacerta } \\
\quad \text { bilineata }\end{array}$ & Italy [48] \\
\hline & $\begin{array}{l}\text { Lacerta } \\
\quad \text { schreiberi }\end{array}$ & Portugal [21, 35], Spain [21] \\
\hline & Podarcis taurica & Hungary [15] \\
\hline & $\begin{array}{l}\text { Podarcis } \\
\text { muralis }\end{array}$ & Germany [42], Italy [1; this study] \\
\hline & $\begin{array}{l}\text { Podarcis } \\
\quad \text { hispanica }\end{array}$ & Portugal [35] \\
\hline & $\begin{array}{l}\text { Podarcis } \\
\text { vaucheri }\end{array}$ & Algeria [52] \\
\hline & Timon lepidus & Portugal [35] \\
\hline & Teira dugesii & Portugal [7] \\
\hline & $\begin{array}{l}\text { Psammodromus } \\
\text { algirus }\end{array}$ & $\begin{array}{l}\text { Algeria [52], Portugal [35], Spain } \\
\text { [29]; Tunisia [10] }\end{array}$ \\
\hline & Timon pater & Algeria [52] \\
\hline $\begin{array}{l}\text { Dermacentor } \\
\text { marginatus }\end{array}$ & Lacerta viridis & Slovakia [56] \\
\hline \multirow[t]{4}{*}{$\begin{array}{l}\text { Haemaphysalis } \\
\text { sulcata }\end{array}$} & $\begin{array}{l}\text { Apathya } \\
\text { cappadocica }\end{array}$ & Turkey [20] \\
\hline & Lacerta media & Turkey [20] \\
\hline & $\begin{array}{l}\text { Psammodromus } \\
\text { algirus }\end{array}$ & Spain [29] \\
\hline & $\begin{array}{l}\text { Podarcis } \\
\quad \text { muralis }\end{array}$ & This study \\
\hline \multirow[t]{2}{*}{$\begin{array}{l}\text { Haemaphysalis } \\
\text { punctata }\end{array}$} & $\begin{array}{l}\text { Psammodromus } \\
\text { algirus }\end{array}$ & Spain [29] \\
\hline & $\begin{array}{l}\text { Podarcis } \\
\quad \text { muralis }\end{array}$ & This study \\
\hline
\end{tabular}

R. raoultii is present [49], involving wild boars [50] and small rodents [31]. Moreover, B. burgdorferi s.l. infects questing I. ricinus, and tissues and ticks from small rodents $[32,40]$.

Due to the variety of tick species and TBD agents in the area, and that previous studies of our group in a close park had shown lizards' involvement in the maintenance of B. lusitaniae [1], we investigated if lizards play a role in the maintenance of ticks and transmitted pathogens. We present here the results of the evaluation of tick infestation and infection by B. burgdorferi s.l. and Rickettsia spp. in attached ticks and lizard tissues.

\section{Materials and Methods}

\section{Study Area}

The research was carried out on the Tuscan side of the TuscanEmilian Apennine National Park, Lucca province, Italy ( $44^{\circ}$ $12^{\prime} \mathrm{N}, 10^{\circ} 22^{\prime}$ E) [40]. Podarcis muralis and Lacerta viridis (Laurenti 1768) are the two Lacertidae reported in the study area [2].

Lizards capture sites $(n=12)$ were located from 800 to 1600 meters above sea level ( $m$ a.s.l.) and were specifically chosen to be an optimal habitat for lizards, having a good sun exposure and abundant refuges. Sites were characterized by different vegetation typologies: open meadows with rocks and bushes; hiking trails with stone walls and tall grass; areas of exposed rocks and mixed deciduous woods dominated by hop hornbeam (Ostrya carpinifolia) and Turkey oaks (Quercus cerris); and, in the upper part of the study area, gravelly soil areas with scarce vegetation at the border of beech (Fagus sylvatica) woods (Online Resource 1).

\section{Lizard and Tick Sampling}

Lizards were captured by a noose affixed to a stick during six sampling sessions in spring and summer (April-August) from 2011 to 2013. Animals were identified by species, age class (adult, young) and sex, according to Vanni and Nistri [57]. Attached ticks were removed with forceps and stored in $70 \%$ ethanol, and were identified by species by using keys from Manilla [28]. In the case the lizard tail detached via tail fracture (a natural escape mechanism in lizards), it was stored in $70 \%$ ethanol. Afterwards, each lizard was released in its capture site. Animal capture and sampling protocols were approved by the Commission for Bioethics and Animal Welfare of the University of Turin.

\section{Laboratory Analyses}

DNA from ticks was extracted by using the DNeasy Blood and Tissue Kit (Qiagen GmbH, Hilden, Germany), while DNA extraction from tail tissues was carried out with MagCore HF16 Automated DNA/RNA purification System and MagCore genomic DNA tissue kit (RBC Bioscience, New Taipei City, Taiwan). Negative controls (distilled water) were added during the extraction to verify for possible crosscontaminations.

Tested ticks included all attached I. ricinus larvae and nymphs, all $H$. punctata, and a sample of $H$. sulcata nymphs, the size of which was determined in order to detect the presence/absence of Rickettsia spp. infection (considering a 95\% confidence level and 20\% expected prevalence).

All DNA tick and tissue samples were analysed for B. burgdorferi s.l. and Rickettsia spp. The infection by B. burgdorferi s.l. was studied by a PCR protocol targeting the intergenic spacer (IGS) region as previously described [44]. Detection of Rickettsia spp. in ticks was performed by targeting the citrate synthase (gltA) [22], OmpA [41] and OmpB genes [46]. Rickettsia spp. detection in lizard tissues was performed by a nested-PCR targeting the $O m p B$ gene [4]. 
Table 2 Bibliographic reports of the infection by B. burgdorferi s.l. and Rickettsia spp. in lizard tissues and attached I. ricinus in Europe and Northern Africa

\begin{tabular}{|c|c|c|c|}
\hline Lizard species & $\begin{array}{l}\text { Pathogens infecting } \\
\text { lizards tissues }\end{array}$ & Pathogens infecting attached Ixodes ricinus & Reference \\
\hline \multirow[t]{6}{*}{ Lacerta agilis } & B. lusitaniae & $\begin{array}{l}\text { B. lusitaniae, B. burgdorferi s.s., } \\
\text { B. burgdorferi s.l. }\end{array}$ & {$[14]$} \\
\hline & B. lusitaniae & Negative to $B$. burgdorferi s.l. & {$[15]$} \\
\hline & N.I. & B. afzelii, B. garinii, B. burgdorferi s.s. & {$[18]$} \\
\hline & N.I. & B. lusitaniae, B. valaisiana & {$[27]$} \\
\hline & N.I. & B. afzelii, B. burgdorferi s.s., $R$. helvetica & {$[55]$} \\
\hline & N.I. & B. lusitaniae & {$[42]$} \\
\hline \multirow{2}{*}{$\begin{array}{l}\text { Lacerta } \\
\text { schreiberi }\end{array}$} & N.I. & R. monacensis, $R$. helvetica & {$[21]$} \\
\hline & $\begin{array}{l}\text { Negative to } \\
\quad \text { B. burgdorferi s.l. }\end{array}$ & B. lusitaniae & {$[35]$} \\
\hline Lacerta viridis & B. lusitaniae & B. lusitaniae, B. afzelii, B. burgdorferi s.s. & {$[15]$} \\
\hline \multirow{4}{*}{$\begin{array}{l}\text { Podarcis } \\
\text { muralis }\end{array}$} & B. lusitaniae & B. lusitaniae & {$[1]$} \\
\hline & N.I. & B. lusitaniae, B. valaisiana & {$[42]$} \\
\hline & R. helvetica & B lusitaniae, B. afzelii, B. valaisiana, B. garinii, & This \\
\hline & $\begin{array}{l}\text { Negative to } \\
\text { B. burgdorferi s.l. }\end{array}$ & $\begin{array}{l}\text { R. monacensis, } R \text {. helvetica, } \\
\text { R. hoogstraalii }\end{array}$ & study \\
\hline $\begin{array}{l}\text { Podarcis } \\
\quad \text { hispanica }\end{array}$ & $\begin{array}{l}\text { Negative to } \\
\text { B. burgdorferi s.l. }\end{array}$ & B. lusitaniae & {$[35]$} \\
\hline Podarcis taurica & B. lusitaniae & B. lusitaniae, B. afzelii, B. burgdorferi s.s. & {$[15]$} \\
\hline \multirow{2}{*}{$\begin{array}{l}\text { Psammodromus } \\
\text { algirus }\end{array}$} & B. lusitaniae & B. lusitaniae & {$[10]$} \\
\hline & B. lusitaniae & B. lusitaniae & {$[35]$} \\
\hline Teira dugesii & $\begin{array}{l}\text { B. lusitaniae, } \\
\text { R. helvetica, } \\
\text { R. monacensis }\end{array}$ & B. lusitaniae, $R$. helvetica, $R$. monacensis & {$[7]$} \\
\hline Timon lepidus & $\begin{array}{l}\text { Negative to } \\
\quad \text { B. burgdorferi s.l. }\end{array}$ & B. lusitaniae & {$[35]$} \\
\hline
\end{tabular}

N.I. not investigated
In all PCR reactions, $2.5 \mu \mathrm{l}$ of DNA sample was tested. In each PCR run, distilled water was added as negative control; DNA from B. afzelii (Nancy strain) and R. conorii (Malish strain) were used as positive controls. The efficiency of the extraction protocol was verified in PCR-negative samples: for tick extracts, by a $16 S$ rDNA PCR [6]; and for tail tissue extracts, by a $c y t B$ gene PCR [23].

Positive amplicons were purified with the ExoSAP-IT PCR Clean-up Kit (GE Healthcare, Chalfont, UK) and sent to an external service (Macrogen, Amsterdam, The Netherlands) for automatic sequencing. Sequences were analysed and edited by using DNASTAR Lasergene software (Madison, WI, USA), and we used BLAST to identify similarities to known sequences (http://blast.ncbi.nlm.nih.gov/blast.cgi).

To confirm B. burgdorferi s.l. genospecies identification, we performed an in silico restriction fragment length polymorphism analysis and a 'virtual hybridization' [47].

\section{Statistical Analysis}

Prevalence and 95\% exact binomial confidence intervals (CI) of infestation by immature I. ricinus and H. sulcata were calculated (BINOMIAL option, PROC FREQ, SAS Institute
1999). Prevalence of infestation by ticks, in young and adult lizards and between sexes, and between lizards and small rodents captured in the same area [31], was compared by Fisher exact test; a two-tailed significance level of $\alpha=0.05$ was adopted. Mean numbers of ticks per host and $95 \% \mathrm{CI}$ as well as negative binomial dispersion parameters $(k)$ were obtained by intercept-only generalized linear models (GLM) with PROCGENMOD in the SAS system. Negative binomial error (log link) was used to take into account aggregated distribution of ticks among hosts [24]. The degree of coinfestation by I. ricinus larvae and nymphs, and by I. ricinus and $H$. sulcata, on the lizards, was tested by the Kappa coefficient (AGREE option, FREQ procedure, SAS Institute 1999). McNemar's chi-square for non-independent observations was calculated to compare the probabilities of infestation by tick species and stages.

Prevalence of infection by $B$. burgdorferi s.l. and Rickettsia spp. was calculated by species/stage of attached tick and in lizard tissues. To take into account for correlation arising from collecting I. ricinus larvae from the same individuals, we used Generalized Estimating Equations (GEE) with repeated measures [9]; this was not applied to nymphs, since few specimens were tested. 
Due to the low number of capture sites, it was not possible to compare tick infestation among vegetation typologies.

\section{Results}

\section{Lizard Capture and Infestation by Ticks}

We captured 107 Podarcis muralis lizards in nine study sites, located in the whole altitudinal range, and collected 16 tails following spontaneous caudal autotomy. Sixty-eight animals $(63.6 \%$; 95\%CI 53.7, 72.6) were infested by ticks. Ticks were exclusively attached in the axillary region.

Adult lizards were significantly more infested than young animals $(p=0.02)$, while no differences were recorded between sexes $(p=0.2)$. The number of infested animals was significantly higher in April-May (78.3\%) than in June $(54.3 \%)$ and August $(50.0 \%)(p=0.02)$.

I. ricinus parasitized 45 lizards (145 larvae, 25 nymphs), while $H$. sulcata infested 37 lizards (119 larvae, 107 nymphs); $H$. punctata (2 larvae) were collected on two lizards.

I. ricinus larvae infested $34.6 \%$ lizards, with a mean number of 1.4 specimens per lizard, and showed an aggregated distribution (negative binomial parameter $k=0.21$; Table 3). They were collected from May to August. Nymphs were collected from April and were absent in August; they parasitized $14.0 \%$ of lizards (Table 3 ). Coinfestation by I. ricinus larvae and nymphs occurred in seven animals, captured in MayJune; the Kappa coefficient $(0.087$; $95 \%$ CI $-0.8,0.25)$ indicated no evidence of coinfestation by the two tick stages beyond chance expectation. Prevalence of infection by larvae was significantly larger than nymphs' prevalence $(p<0.001)$. Infestation prevalence by $I$. ricinus larvae in lizards was significantly lower $(p<0.001)$ than the infestation prevalence of Apodemus spp. mice in the area (54.4\%), while nymphs infestation was significantly higher $(p<0.001 ; 3.7 \%$ in mice) [31].

H. sulcata larvae were collected on $13.1 \%$ of the animals, in May and August only. Nymphs infested $24.3 \%$ of lizards (Table 3); they were present in all months, with a higher number of infested lizards in April-May. Only three lizards (two captured in August, one in May) were simultaneously infested by both stages.

Coinfestation by $I$. ricinus and $H$. sulcata occurred in 14 animals; there was no evidence of coinfestation by the two species beyond chance expectation (Kappa coefficient $-0.06 ; 95 \%$ CI $-0.25,0.12$ ). The prevalence of infection by I. ricinus and $H$. sulcata on lizards was not significantly different ( $p=0.28)$. Eleven of the coinfested lizards were captured in the same study site, located at $800 \mathrm{~m}$ a.s.l. and characterized by mixed oak wood. In this site, I. ricinus, $H$. sulcata and $H$. punctata were simultaneously collected also by dragging in August 2013 (unpublished data).

The two $H$. punctata larvae were collected on two lizards, one was simultaneously infested by $H$. sulcata ( $n=13$ larvae), and the other by $H$. sulcata and I. ricinus (22 and 1 larvae, respectively).

Ten out of the 16 lizards, which tails detached, were infested by ticks; six animals by $H$. sulcata only, and four by both $I$. ricinus and $H$. sulcata.

\section{Infection by TBD Agents in Ticks and Tissues from Lizards}

B. burgdorferi s.l. was detected in $3.5 \%$ I. ricinus larvae and in $8 \%$ nymphs (Table 4). B. lusitaniae and B. valaisiana were infecting one nymph and one larva each; $B$. garinii and B. afzelii were detected in two larvae. It was not possible to identify the genospecies in one positive larva. The obtained sequences were $100 \%$ identical to those previously detected in questing ticks in the study area [40]. The seven positive ticks were collected from six lizards, since one lizard hosted one larva and one nymph, both positive to B. lusitaniae. They were captured in three study sites at 800-1145 $\mathrm{m}$ a.s.l.

I. ricinus were also infected by Rickettsia spp. (18.1\% larvae and $24.3 \%$ nymphs), namely $R$. monacensis, $R$. helvetica and $R$. hoogstraalii. $R$. hoogstraalii was detected in H. sulcata nymphs as well (Table 4). R. monacensis gltA and OmpA sequences and $R$. helvetica gltA sequence were $100 \%$ similar to reference sequences deposited in GenBank (KU310588, LN794217). We could amplify DNA fragments of $R$. hoogstraalii encoding for gltA and $O m p B$ genes, but not

Table 3 Infestation of P. muralis lizards by immature I. ricinus and H. sulcata, Tuscan-Emilian National Park, Italy, 2011-2013

\begin{tabular}{|c|c|c|c|c|}
\hline \multirow{2}{*}{$\begin{array}{l}\text { Tick species } \\
\text { Ticks stage }\end{array}$} & \multicolumn{2}{|l|}{ Ixodes ricinus } & \multicolumn{2}{|c|}{ Haemaphysalis sulcata } \\
\hline & Larvae & Nymphs & Larvae & Nymphs \\
\hline No. infested hosts; $\%$ prevalence of infestation $(95 \% \mathrm{CI})$ & $37 ; 34.6(25.6-44.4)$ & $15 ; 14.0(8.1-22.1)$ & $14 ; 13.1(7.3-21.0)$ & $26 ; 24.3(16.5-33.5)$ \\
\hline Mean no. ticks/captured host (95\%CI) & $1.4(0.87-2.1)$ & $0.23(0.13-0.42)$ & $1.1(0.4-2.8)$ & $1.0(0.6-1.7)$ \\
\hline Mean no. ticks/infested host (95\%CI) & $3.9(2.9-5.3)$ & $1.7(1.1-2.4)$ & $8.5(6.0-11.9)$ & $4.1(3.0-5.6)$ \\
\hline$k(95 \% \mathrm{CI})$ & $0.21(0.13-0.33)$ & $0.18(0.07-0.51)$ & $0.04(0.02-0.08)$ & $0.13(0.07-0.22)$ \\
\hline
\end{tabular}

$k$ negative binomial dispersion parameter 
Table 4 Prevalence of B. burgdorferi s.1 and SFG Rickettsiae in ticks feeding on P. muralis lizards in the Tuscan-Emilian National Park, Italy, 20112013

\begin{tabular}{|c|c|c|c|}
\hline \multirow{2}{*}{$\begin{array}{l}\text { Tick species } \\
\text { Ticks stage (no. of tested ticks) }\end{array}$} & \multicolumn{2}{|l|}{ Ixodes ricinus } & \multirow{2}{*}{$\begin{array}{l}\text { Haemaphysalis sulcata } \\
\text { Nymphs (14) }\end{array}$} \\
\hline & Larvae (142) & Nymphs (25) & \\
\hline $\begin{array}{l}\% \text { prevalence of } B . \text { burgdorferi } \text { s.l. } \\
(95 \% \mathrm{CI}) \text {; genospecies (no. positive ticks) }\end{array}$ & $\begin{array}{l}3.7(1.5-8.9) ; \\
\text { B. lusitaniae }(1), \\
\text { B. valaisiana }(1), \\
\text { B. garinii }(1), \\
\text { B. afzelii }(1), \text { nd (1) }\end{array}$ & $\begin{array}{l}8.0(1.0-26.0) ; \\
\text { B. lusitaniae }(1), \\
\text { B. valaisiana }(1)\end{array}$ & $0(0.0-23.2)$ \\
\hline $\begin{array}{l}\% \text { prevalence of Rickettsia spp. } \\
\text { (95\%CI); species (no. positive ticks) }\end{array}$ & $\begin{array}{l}18.1(10.9-28.7) ; \\
\text { R. monacensis }(11) ; \text { R. helvetica (5); } \\
\text { R. hoogstraalii (6), nd (3) }\end{array}$ & $\begin{array}{l}12.0(2.5-31.2) \\
\text { R. monacensis }(2) ; \text { nd }(1)\end{array}$ & $\begin{array}{l}21.4(4.7-50.8) ; \\
\text { R. hoogstraalii }(3)\end{array}$ \\
\hline
\end{tabular}

95\% CI for I. ricinus larvae were calculated using GEE with repeated measures; exact binomial 95\%CI are given for I. ricinus and $H$. sulcata nymphs

the $O m p A$ gene, as reported by other authors [3, 36]. Our gltA sequences, from both I. ricinus and H. sulcata (GenBank Accession No. KY418024, KY418025), showed 100\% similarity to the Rickettsia endosymbiont of $H$. punctata isolate Hae69 from Spain (EU303311) and 99\% to the endosymbiont of $H$. sulcata from Croatia (DQ081187); these endosymbionts have been subsequently classified as $R$. hoogstraalii by Duh et al. [13]. The $O m p B$ gene (GenBank Accession No. KY418026) had $99 \%$ similarity to $R$. hoogstraalii from soft ticks in the USA (EF629536).

Rickettsia spp.-positive ticks $(n=31)$ were collected from 17 lizards, that had from one to seven positive ticks attached. These animals were captured in five different sites, three of which were the same in which $B$. burgdorferi s.l.-positive ticks were detected; the two additional sites were at higher altitude (1270 and $1440 \mathrm{~m}$ a.s.1.).

Coinfection by B. afzelii and R. monacensis was observed in one $I$. ricinus larva.

The two $H$. punctata larvae did not harbour any bacteria.

We did not detect B. burgdorferi s.l. in tail tissues, while one of the tails was positive to Rickettsia spp. $(6.25 \%$; $95 \% \mathrm{CI}$ 0.16-30.2). The $O m p B$ sequence (GenBank Accession No. KY434315) was $99 \%$ similar to $R$. helvetica from questing I. ricinus in Germany (HQ232251). The positive tissue belonged to a lizard captured in an oak wood site at $1145 \mathrm{~m}$ a.s.1., which was infested by 6 I. ricinus (negative to PCR) and 9 H. sulcata (not tested by PCR) larvae at the moment it was captured.

\section{Discussion}

The detection of B. burgdorferi s.l. and SFG Rickettsiae in attached ticks, and of $R$. helvetica in a tail tissue, supports the hypothesis that lizards are involved in the transmission cycle of tick-borne pathogens in the Tuscan-Emilian Apennine National Park, where they serve as feeding hosts for $I$. ricinus and $H$. sulcata immatures mainly.
I. ricinus immatures also infest small rodents in our study area [31], but we observed that lizards are better hosts for nymphs and are significantly more infested, compared to mice. This finding confirms the results of a previous study in a close hilly area in Tuscany [1]. Contrarily to this older study, we registered an overall lower I. ricinus infestation prevalence in lizards, lower mean numbers of ticks per lizard, and we detected a higher I. ricinus aggregation. These differences may be due to the recent spread of I. ricinus in the Northern Apennines [40], with a consequent lower tick burden, and to the major environmental variability and harsher climatic conditions in this mountain area, which could lead to a more heterogeneous frequency of questing ticks.

Also, $H$. sulcata were abundant and aggregated on lizards. H. sulcata is a xerophilic tick species present in the Mediterranean basin, but it is abundant in the park area, where adults feed on mouflons (Ovis orientalis musimon) [40]. Although its immatures are recognized parasites of reptiles [58], scarce bibliographic findings on lizards are available (Table 1).

Rodents and lizards are reported as hosts for $H$. punctata immatures by Walker et al. [58], but we found just two attached specimens on lizards and none on small rodents [30, 31], although this tick species is widespread in the Northern Apennines [40]. We can thus hypothesise that they preferentially feed on birds, that are also reported as preferential hosts for $H$. punctata immatures [5], or other small mammals species in the study area. The two larvae we collected on lizards were not infected by TBD agents. However, previous studies showed H. punctata infection by B. burgdorferi s.l. [54]. It would thus be interesting to further investigate $H$. punctata infection by the pathogens that cause TBD cases in the Park area [49, 51]. Likewise, lizards on do not appear to be attractive hosts for D. marginatus immatures, although we abundantly collected this tick species by dragging and on small rodents [30, 31, 40]. This may be due to its nidicolous habits, that make immatures preferentially live in small rodents nests; nevertheless, D. marginatus was reported to infest lizards by other authors [56]. 
B. burgdorferi infection prevalence in attached nymphs, and the heterogeneity of genospecies, mirrors previous findings in questing ticks in the area [40]. B. lusitaniae was detected in one $I$. ricinus nymph and one larva; however, other immatures were infected by $B$. valaisiana, $B$. garinii and B. afzelii. B. afzelii had been already reported in I. ricinus larvae feeding on lizards in Hungary [15] and Slovakia [27]. Since transovarial transmission of $B$. burgdorferi s.l. is unlikely [43], the finding of genospecies other than $B$. lusitaniae in attached larvae may be explained by the involvement of lizards in their maintenance (systemic infection), by a precedent interrupted blood-meal taken on an infected reservoir host, or by the cofeeding transmission among larvae and nymphs feeding in close proximity [17]. This last hypothesis is countered by the low coinfestation by I. ricinus nymphs and larvae observed on our lizards; all these possible explanations deserve further investigations anyway.

No lizard tails were infected by $B$. lusitaniae, contrarily to what was observed in P. muralis tissues in a close study area [1]. However, we tested a small number of tissue samples.

Tick immatures were also infected by SFG rickettsiae. We identified $R$. helvetica, $R$. monacensis and $R$. hoogstraalii, which are added to $R$. slovaca and $R$. raoultii, the two other species that have a natural focus of transmission in our study area, associated to D. marginatus [30]. We detected $R$. helvetica in few attached I. ricinus larvae, as previously reported in studies on lizards in mountain areas of the Iberian Peninsula [21] and Slovakia [56], Madeira island [7] and the Netherlands [55]. The fact that $R$. helvetica was also identified in a tail tissue and that we observed ticks exclusively feeding in the axillary region indicates a disseminated infection. This is in agreement with the hypothesis that lizards may act as amplifiers of this rickettsia, which is considered a potential pathogen for humans [53].

De Sousa et al. [7] hypothesise that lizards may also be reservoirs of $R$. monacensis, the agent of spotted fever rickettsioses [38]. As reported in previous studies in Spain and Portugal, $R$. monacensis was the dominant rickettsia species in lizard ticks and infected attached I. ricinus larvae and nymphs [7,21].

Surprisingly, we detected a third rickettsial species in I. ricinus larvae, $R$. hoogstraalii, that we also identified in attached $H$. sulcata. This rickettsia is documented for the first time in Italy. $R$. hoogstraalii has been originally detected in H. sulcata from sheep and goats in Croatia, and it is closely related to Rickettsia felis [12]. Duh et al. [13] showed that it causes a cytopathic effect in Vero cells and different arthropod cell lines, but its pathogenicity in vertebrate hosts is unknown. Other reports from Europe refer to infection in Haemaphysalis spp. ticks: $H$. punctata and $H$. sulcata in Spain [29, 39], H. punctata in Cyprus [3] and H. parva in Turkey [20,36]. In other continents, $R$. hoogstraalii was associated to soft ticks $[8,19,33,37]$. Our finding of this organism not only in
H. sulcata but also in I. ricinus could suggest a spillover of the rickettsia into I. ricinus, determined either by the intake of rickettsemic bloodmeals from lizards or by the cofeeding of the two tick species [59]. This same hypothesis was made by Marquez [29] in Spain, who observed $R$. hoogstraalii in both $H$. sulcata and $H$. punctata sharing their feeding hosts, $P$. algirus lizards in particular.

Such bacterial exchange could have consequences on ticks as vectors of diseases, due to the varying interactions that bacteria can have in the tick microbiome [16]. Vaclav et al. [56] studied the coinfection by Anaplasma spp., Rickettsia spp. and B. lusitaniae in I. ricinus attached on green lizards in Central Europe and concluded that the risk of tick infection with one pathogen may be dependent of the other pathogens. In particular, the authors showed positive interactions between Rickettsia spp. and $B$. lusitaniae that could have important public health consequences, since the simultaneous transmission of multiple pathogens was shown to alter host susceptibility and immune response, and increase the severity of clinical signs [25]. On the other hand, infections by rickettsial endosymbionts may preclude secondary infections with pathogenic rickettsiae [16, 26, 34, 59]. Further studies are needed to evaluate the possible pathogenicity of $R$. hoogstraalii to mammals; however, its infection in I. ricinus could have public health consequences, either favouring or precluding the infection with other agents of TBD.

In conclusion, our investigation showed the implication of another vertebrate host (lizard) in the maintenance of ticks and tick-borne bacteria in the study area, and the presence of rickettsial agents that had not been discovered in previous studies. This underlines, once again, the high complexity of tick-borne diseases systems. To tackle such complexity and control the emergence of TBD, we need to unravel the interactions in bacterial-vector-vertebrate communities both from an ecological and a metagenomic point of view.

Acknowledgments The UTCB Lucca (ex Corpo Forestale dello Stato, Ufficio Territoriale per la Biodiversità) provided accommodation, animal handling facilities and valuable help; a special thanks to Cecilia Ambrogi and to Maurizio Pieroni, who helped with fieldwork. Eliana C. Guillemi, INTA, Argentina, helped with labwork.

The study was funded by the University of Torino. The work of L. Tomassone and R. da Sousa was done under the frame of EurNegVec COST Action TD1303.

\section{Compliance with Ethical Standards}

Conflict of Interest The authors declare no conflicts of interest.

\section{References}

1. Amore G, Tomassone L, Grego E, Ragagli C, Bertolotti L, Nebbia $\mathrm{P}$, et al (2007) Borrelia lusitaniae in immature Ixodes ricinus (Acari: Ixodidae) feeding on common wall lizards in Tuscany, central Italy. J Med Entomol 44:303-307 
2. Bonani S, Bruni A, Cappelli F, Dondini G, Olivari S, Perilli E, Vergari S (2002) Faggete dell'Appennino settentrionale: habitat e vertebrati. Quaderni conservazione habitat, Ed. Arcari, Mantova

3. Chochlakis D, Ioannou I, Sandalakis V, Dimitriou T, Kassinis N, Papadopoulos B, et al (2012) Spotted fever group Rickettsiae in ticks in Cyprus. Microb Ecol 63:314-323. doi:10.1007/s00248011-9926-4

4. Choi YJ, Lee SH, Park KH, Koh YS, Lee KH, Baik HS, et al (2005) Evaluation of PCR-based assay for diagnosis of spotted fever group rickettsiosis in human serum samples. Clin Diagn Lab Immunol 12: 759-763

5. Cringoli G, Iori A, Rinaldi L, Veneziano V, Genchi C (2005) Zecche. Rolando Editore, Napoli

6. D'Oliveira C, van der Weide M, Jacquiet P, Jongejan F (1997) Detection of Theileria annulata by the PCR in ticks (Acari: Ixodidae) collected from cattle in Mauritania. Exp Appl Acarol 21:279-291

7. De Sousa R, Lopes de Carvalho I, Santos AS, Bernardes C, Milhano N, Jesus J, et al (2012) Role of the lizard Teira dugesii as a potential host for Ixodes ricinus tick-borne pathogens. Appl Environ Microbiol 78:3767-3769. doi: 10.1128/AEM.07945-11

8. Dietrich M, Lebarbenchon C, Jaeger A, Le Rouzic C, Bastien M, Lagadec E, et al (2014) Rickettsia spp. in seabird ticks from western Indian Ocean islands, 2011-2012. Emerg Infect Dis 20:838-842. doi:10.3201/eid2005.131088

9. Diggle P, Heagerty P, Liang KY, Zeger S (2002) Analysis of longitudinal data. Oxford University Press, New York

10. Dsouli N, Younsi-Kabachii H, Postic D, Nouira S, Gern L, Bouattour A (2006) Reservoir role of lizard Psammodromus algirus in transmission cycle of Borrelia burgdorferi sensu lato (Spirochaetaceae) in Tunisia. J Med Entomol 43:737-742

11. Dudek K, Skórka P, Sajkowska ZA, Ekner-Grzyb A, Dudek M, Tryjanowski P (2016) Distribution pattern and number of ticks on lizards. Ticks Tick Borne Dis 7:172-179. doi:10.1016/j.ttbdis.2015. 10.014

12. Duh D, Punda-Polić V, Trilar T, Petrovec M, Bradarić N, Avsic-Zupanc T (2006) Molecular identification of Rickettsia felis-like bacteria in Haemaphysalis sulcata ticks collected from domestic animals in southern Croatia. Ann N Y Acad Sci 1078:347-351

13. Duh D, Punda-Polic V, Avsic-Zupanc T, Bouyer D, Walker DH, Popov VL, et al (2010) Rickettsia hoogstraalii sp. nov., isolated from hard- and soft-bodied ticks. Int J Syst Evol Microbiol 60: 977-984. doi: 10.1099/ijs.0.011049-0

14. Ekner A, Dudek K, Sajkowska Z, Majláthová V, Majláth I, Tryjanowski P (2011) Anaplasmataceae and Borrelia burgdorferi sensu lato in the sand lizard Lacerta agilis and co-infection of these bacteria in hosted Ixodes ricinus ticks. Parasit Vectors 4:182. doi: 10.1186/1756-3305-4-182

15. Földvári G, Rigó K, Majláthová V, Majláth I, Farkas R, Pet'ko B (2009) Detection of Borrelia burgdorferi sensu lato in lizards and their ticks from Hungary. Vector Borne Zoonotic Dis 9:331-336. doi:10.1089/vbz.2009.0021

16. Gall CA, Reif KE, Scoles GA, Mason KL, Mousel M, Noh SM, Brayton KA (2016) The bacterial microbiome of Dermacentor andersoni ticks influences pathogen susceptibility. ISME J 10: 1846-1855. doi:10.1038/ismej.2015.266

17. Gern L, Rais O (1996) Efficient transmission of Borrelia burgdorferi between cofeeding Ixodes ricinus ticks (Acari: Ixodidae). J Med Entomol 33:189-192

18. Gryczyńska-Siemiątkowska A, Siedlecka A, Stańczak J, Barkowska M (2007) Infestation of sand lizards (Lacerta agilis) resident in the northeastern Poland by Ixodes ricinus (L.) ticks and their infection with Borrelia burgdorferi sensu lato. Acta Parasit 52:165. doi:10.2478/s11686-007-0015-2
19. Kawabata H, Ando S, Kishimoto T, Kurane I, Takano A, Nogami S, et al (2006) First detection of Rickettsia in soft-bodied ticks associated with seabirds, Japan. Microbiol Immunol 50:403-406

20. Keskin A, Bursali A, Keskin A, Tekin S (2016) Molecular detection of spotted fever group rickettsiae in ticks removed from humans in Turkey. Ticks Tick Borne Dis 7:951-953. doi:10.1016/j.ttbdis. 2016.04.015

21. Kubelová M, Papoušek I, Bělohlávek T, de Bellocq JG, Baird SJ, Široký P (2015) Spotted fever group rickettsiae detected in immature stages of ticks parasitizing on Iberian endemic lizard Lacerta schreiberi Bedriaga, 1878. Ticks Tick Borne Dis 6:711-714. doi: 10.1016/j.ttbdis.2015.06.003

22. Labruna MB, Whitworth T, Horta MC, Bouyer DH, JW MB, Pinter A, et al (2004) Rickettsia species infecting Amblyomma cooperi ticks from an area in the state of São Paulo, Brazil, where Brazilian spotted fever is endemic. J Clin Microbiol 42:90-98

23. Lee JH, Hassan H, Hill G, Cupp EW, Higazi TB, Mitchell CJ, et al (2002) Identification of mosquito avian-derived bloodmeals by polymerase chain reaction-heteroduplex analysis. Am J Trop Med Hyg 66:599-604

24. Littell RC, Milliken GA, Stroup WW, Wolfinger RD, Schabenberger O (2006) SAS for mixed models, 2nd ed. SAS®Institute, Cary

25. Lommano E, Bertaiola L, Dupasquier C, Gern L (2012) Infections and coinfections of questing Ixodes ricinus ticks by emerging zoonotic pathogens in western Switzerland. Appl Environ Microbiol 78:4606-4612. doi:10.1128/AEM.07961-11

26. Macaluso KR, Sonenshine DE, Ceraul SM, Azad AF (2002) Rickettsial infection in Dermacentor variabilis (Acari: Ixodidae) inhibits transovarial transmission of a second Rickettsia. J Med Entomol 39:809-813

27. Majláthová V, Majláth I, Hromada M, Tryjanowski P, Bona M, Antczak M, et al (2008) The role of the sand lizard (Lacerta agilis) in the transmission cycle of Borrelia burgdorferi sensu lato. Int $\mathrm{J}$ Med Microbiol 298:161-167. doi:10.1016/j.ijmm.2008.03.005

28. Manilla G (1998) Acari, Ixodida (Fauna d'Italia 36). Edizioni Calderoni, Bologna

29. Márquez FJ (2008) Spotted fever group Rickettsia in ticks from southeastern Spain natural parks. Exp Appl Acarol 45:185-194. doi:10.1007/s10493-008-9181-7

30. Martello E, Selmi M, Ragagli C, Ambrogi C, Stella MC, Mannelli A, Tomassone L (2013) Rickettsia slovaca in immature Dermacentor marginatus and tissues from Apodemus spp. in the northern Apennines, Italy. Ticks Tick Borne Dis 4:518-521. doi:10. 1016/j.ttbdis.2013.07.002

31. Martello E, Mannelli A, Ragagli C, Ambrogi C, Selmi M, Ceballos LA, Tomassone L (2014a) Range expansion of Ixodes ricinus to higher altitude, and co-infestation of small rodents with Dermacentor marginatus in the northern Apennines, Italy. Ticks Tick Borne Dis 5:970-974. doi:10.1016/j.ttbdis.2014.07.021

32. Martello E, Mannelli A, Ragagli C, Selmi M, Ambrogi C, Grego E, et al (2014b) Use of small rodents for the surveillance of agents and vectors of tick-borne zoonoses in the northern Apennines, Italy. Proceedings of the $1^{\text {st }}$ conference on neglected vectors and vectorborne diseases (EurNegVec). Parasit Vectors 7(Suppl 1):O36

33. Mattila JT, Burkhardt NY, Hutcheson HJ, Munderloh UG, Kurtti TJ (2007) Isolation of cell lines and a rickettsial endosymbiont from the soft tick Carios capensis (Acari: Argasidae: Ornithodorinae). J Med Entomol 44:1091-1101

34. Niebylski ML, Peacock MG, Fischer ER, Porcella SF, Schwan TG (1997) Characterization of an endosymbiont infecting wood ticks, Dermacentor andersoni, as a member of the genus Francisella. Appl Environ Microbiol 63:3933-3940

35. Norte AC, Alves da Silva A, Alves J, da Silva LP, Núncio MS, Escudero R, et al (2015) The importance of lizards and small 
mammals as reservoirs for Borrelia lusitaniae in Portugal. Environ Microbiol Rep 7:188-193. doi: 10.1111/1758-2229.12218

36. Orkun Ö, Karaer Z, Çakmak A, Nalbantoğlu S (2014) Spotted fever group rickettsiae in ticks in Turkey. Ticks Tick Borne Dis 5:213218. doi:10.1016/j.ttbdis.2012.11.018

37. Pader V, Nikitorowicz Buniak J, Abdissa A, Adamu H, Tolosa T, Gashaw A, et al (2012) Candidatus Rickettsia hoogstraalii in Ethiopian Argas persicus ticks. Ticks Tick Borne Dis 3:338-345. doi:10.1016/j.ttbdis.2012.10.021

38. Parola P, Paddock CD, Socolovschi C, Labruna MB, Mediannikov O, Kernif T, et al (2013) Update on tick-borne rickettsioses around the world: a geographic approach. Clin Microbiol Rev 26:657-702. doi: 10.1128/CMR.00032-13

39. Portillo A, Santibáñez P, Santibáñez S, Pérez-Martínez L, Oteo JA (2008) Detection of Rickettsia spp. in Haemaphysalis ticks collected in La Rioja, Spain. Vector Borne Zoonotic Dis 8:653-658. doi: 10.1089/vbz.2007.0272

40. Ragagli C, Mannelli A, Ambrogi C, Bisanzio D, Ceballos LA, Grego E, et al (2016) Presence of host-seeking Ixodes ricinus and their infection with Borrelia burgdorferi sensu lato in the northern Apennines, Italy. Exp Appl Acarol 69:167-178. doi:10.1007/ s10493-016-0030-9

41. Regnery RL, Spruill CL, Plikaytis BD (1991) Genotypic identification of rickettsiae and estimation of intraspecies sequence divergence for portions of two rickettsial genes. J Bacteriol 173:15761589

42. Richter D, Matuschka FR (2006) Perpetuation of the Lyme disease spirochete Borrelia lusitaniae by lizards. Appl Environ Microbiol 72:4627-3462

43. Richter D, Debski A, Hubalek Z, Matuschka FR (2012) Absence of Lyme disease spirochetes in larval Ixodes ricinus ticks. Vector Borne Zoonotic Dis 12:21-27. doi: 10.1089/vbz.2011.0668

44. Rijpkema SG, Molkenboer MJ, Schouls LM, Jongejan F, Schellekens JF (1995) Simultaneous detection and genotyping of three genomic groups of Borrelia burgdorferi sensu lato in Dutch Ixodes ricinus ticks by characterization of the amplified intergenic spacer region between 5S and 23S rRNA genes. J Clin Microbiol 33:3091-3095

45. Rizzoli A, Silaghi C, Obiegala A, Rudolf I, Hubálek Z, Földvári G, Plantard O, Vayssier-Taussat M, Bonnet S, Spitalská E, Kazimírová M (2014) Ixodes ricinus and its transmitted pathogens in urban and peri-urban areas in Europe: new hazards and relevance for public health. Front Public Health 2:251. doi: 10.3389/fpubh.2014.00251

46. Roux V, Raoult D (2000) Phylogenetic analysis of members of the genus Rickettsia using the gene encoding the outer membrane protein rOmpB (ompB). Int J Syst Evol Microbiol 50:1449-1455

47. Rudenko N, Golovchenko M, Grubhoffer L, Oliver Jr JH (2009) Borrelia carolinensis sp. nov., a new (14th) member of the Borrelia burgdorferi sensu lato complex from the southeastern region of the
United States. J Clin Microbiol 47:134-141. doi:10.1128/JCM. 01183-08

48. Scali S, Manfredi MT, Guidali F (2001) Lacerta bilineata (Reptilia, Lacertidae) as a host of Ixodes ricinus (Acari, Ixodidae) in a protected area of northern Italy. Parassitologia 43:165-168

49. Selmi M, Bertolotti L, Tomassone L, Mannelli A (2008) Rickettsia slovaca in Dermacentor marginatus and tick-borne lymphadenopathy, Tuscany, Italy. Emerg Infect Dis 14:817-820. doi:10.3201/ eid1405.070976

50. Selmi M, Martello E, Bertolotti L, Bisanzio D, Tomassone L (2009) Rickettsia slovaca and Rickettsia raoultii in Dermacentor marginatus ticks collected on wild boars in Tuscany, Italy. J Med Entomol 46:1490-1493

51. Selmi M, Bertolotti L, Bisanzio D, Mattei R, Pagani A, Mazzatenta C, Mannelli A (2010) Ixodes ricinus as vector of human tick borne zoonoses in Tuscany. International Conference EDEN 2010, Emerging Vector-borne Diseases in a Changing European Environment, Montpellier, France: 6

52. Soualah-Alila H, Bouslama Z, Amr Z, Bani Hani R (2015) Tick infestations (Acari: Ixodidae) on three lizard species from Seraidi (Annaba District), northeastern Algeria. Exp Appl Acarol 67:159163. doi:10.1007/s10493-015-9932-1

53. Sprong H, Wielinga PR, Fonville M, Reusken C, Brandenburg AH, Borgsteede F, et al (2009) Ixodes ricinus ticks are reservoir hosts for Rickettsia helvetica and potentially carry flea-borne Rickettsia species. Parasit Vectors 2:41. doi: 10.1186/1756-3305-2-41

54. Tälleklint L (1996) Lyme borreliosis spirochetes in Ixodes ricinus and Haemaphysalis punctata ticks (Acari: Ixodidae) on three islands in the Baltic Sea. Exp Appl Acarol 20:467. doi:10.1007/ BF00053310

55. Tijsse-Klasen E, Fonville M, Reimerink JH, Spitzen-van der Sluijs A, Sprong H (2010) Role of sand lizards in the ecology of Lyme and other tick-borne diseases in the Netherlands. Parasit Vectors 3:42. doi: 10.1186/1756-3305-3-42

56. Václav R, Ficová M, Prokop P, Betáková T (2011) Associations between coinfection prevalence of Borrelia lusitaniae, Anaplasma sp., and Rickettsia sp. in hard ticks feeding on reptile hosts. Microb Ecol 61:245-253. doi: 10.1007/s00248-010-9736-0

57. Vanni S, Nistri A (2006) Atlante degli Anfibi e dei Rettili della Toscana. Ed. Museo di Storia Naturale dell'Università degli Studi di Firenze Sezione di Zoologia "La Specola", Regione Toscana Giunta Regionale Assessorato all'Ambiente, Firenze, Italy

58. Walker AR, Bouattour A, Camicas JL, Estrada-Peña A, Horak IG, Latif AA, et al (2003) Ticks of domestic animals in Africa: a guide to identification of species. Bioscience Reports, Edinburgh ISBN: 0-9545173-0-X

59. Wright CL, Sonenshine DE, Gaff HD, Hynes WL (2015) Rickettsia parkeri transmission to Amblyomma americanum by cofeeding with Amblyomma maculatum (Acari: Ixodidae) and potential for spillover. J Med Entomol 52:1090-1095. doi:10.1093/jme/tjv086 